\title{
Narrating the Russian Revolution: Institutionalism and Continuity across Regime Change
}

\author{
DON K. ROWNEY
}

\section{Department of History, Bowling Green State University}

The vigorous revival of institutionalist theories and methods among economists, political scientists, and other social scientists has prompted a broad reconsideration of how political and economic preferences are transformed into social outcomes. In much of the professional literature, this change has stimulated a shift away from behavioral and empirical methods to those that rely on interpretation of the historical evolution of policies in an organizational framework. Focusing on topics as disparate as the implementation of Keynesian economic policies in the 1930s, United States civil service reform at the turn of the twentieth century, or the evolution of property and other rights in early modern England, institutionalist studies by sociologists, political scientists, and economists have, increasingly, addressed problems by using historical narratives. ${ }^{1}$

In this essay I make two arguments as a historian who applies institutionalist theories and methods, critically, to historical problems. I argue that the outcomes of the Russian Revolution of 1917 were more continuous with the Russian past than either revolutionary elites or some historians have been prepared to concede. Continuities were particularly evident insofar as many state organizational functions, policies, and policy outcomes were concerned. Such limiting and shaping pre-revolutionary influences as an increasing number of scholars have identified, moreover, can be seen to have emerged well before Russia's entry into World War I. If the revolution and its aftermath are narrated simply as twentieth-century political, social, or cultural history, their mean-

Acknowledgments: The author thanks Susan R. Carlton, Edward F. McClennen, Walter M. Pintner, William G. Rosenberg, Peter Way, and the anonymous CSSH reviewers for many helpful criticisms and insights during the gestation of this essay.

1 For example, Margaret Weir and Theda Skocpol, "State Structures and the Possibilities for 'Keynesian' Responses to the Great Depression in Sweden, Britain, and the United States,' in Bringing the State Back In, Peter B. Evans, Dietrich Rueschemeyer, and Theda Skocpol, eds. (Cambridge, U.K. 1985), 107-68; Stephen Skowronek, Building a New American State. The Expansion of National Administrative Capacities, 1877-1920 (Cambridge, U.K., 1982); Douglass C. North and Barry R. Weingast, "Constitutions and Commitment: The Evolution of Institutions Governing Public Choice in Seventeenth-Century England," Journal of Economic History 49 (Dec. 1989): $803-32$.

0010-4175/05/79-105 \$9.50 @ 2005 Society for Comparative Study of Society and History 
ing for Russian history and for the study of social discontinuities and regime changes will elude us.

I also argue, however, that institutionalism poses considerable risks in the analysis of the relationship between policy preferences and outcomes-especially for the study of regime change on the scale that one finds in the Revolution of 1917. I argue that the most influential exponent of the institutionalist interpretation of the Russian Revolution, Theda Skocpol, failed to demonstrate the institutional or structural constraints she claimed were imposed upon the Revolution: institutionalist theoretical presuppositions were privileged over empirical findings. I refer to these difficulties collectively as "the Skocpol problem" owing to her substantial and continuing influence on the field of historical-institutional studies, especially in political sociology and comparative politics. $^{2}$ Given her stature in these fields, it is the more remarkable that she has not attempted to redress the empirical and theoretical problems posed by her treatment of the Russian Revolution in her now classic work, States and Social Revolutions. ${ }^{3}$

The "Skocpol problem" is, in fact, two problems. First, States and Social Revolutions rests upon a poor grasp of the relevant (at the time of writing) historical literature. But, second and surprisingly, this work, in my view, rests upon a comparatively naïve understanding of institutions and of their dependence on history. More recent work by Skocpol has addressed the second deficiency to some extent, but not the first. As a result, her interpretation of mass social revolution, while regarded by some students of institutionalism as "paradigmatic" and "classic," yields a distorted understanding of institutional survival across an era of regime change and social discontinuity such as that found in revolutionary and post-revolutionary Russia. ${ }^{4}$

These problems are part of a broad misunderstanding of the outcomes of the Russian revolution so far as the state is concerned: the post-revolutionary state was the product of many factors including industrialization policy, the structure

2 Commentaries that locate her work within this body of scholarship include: Peter A. Hall and Rosemary C. R. Taylor, "Political Science and the Three New Institutionalisms," Political Studies 44 (1996):936-57; David B. Robertson, "The Return to History and the New Institutionalism in American Political Science," Social Science History 17 (Spring, 1993):1-36; Ellen M. Immergut, "The Theoretical Core of the New Institutionalism," Politics and Society 26 (Mar. 1998):5-34.

3 Theda Skocpol, States and Social Revolutions. A Comparative Analysis of France, Russia and China (New York, 1979). See her more recent thoughts in Social Revolutions in the Modern World (New York, 1994), 3-22, and 301-40. Her views on historical institutionalism specifically may be found in Theda Skocpol and Paul Pierson, "Historical Institutionalism in Contemporary Political Science," in Political Science: State of the Discipline, Ira Katznelson and Helen V. Milner, eds. (New York, 2002), 693-721; and Theda Skocpol, "Why I am a Historical Institutionalist," Polity 28, 1 (Fall 1995):103-6.

4 It won the 1979 C. Wright Mills Award and the American Sociological Association award for Distinguished Contribution to Scholarship in 1980. "Paradigmatic" status is claimed by Ellen M. Immergut, among others, in "The Normative Roots of the New Institutionalism: Historical-Institutionalism and Comparative Policy Studies," at http://www.uni-konstanz.de/Verwiss/Immergut/ publications/kon3.htm, 38. The "classic" claim is ubiquitous among retrospective reviewers. 
of state organizations, World War I and its aftermath, and the mass social energies mobilized during the Revolutionary year of 1917 and the ensuing Civil War. An understanding of these phenomena within the confines of an analysis of long-term social development, selected state policies, and intrusive external events without an adequate grasp of the relevant institutional dynamics and range of historical narratives, produces a research strategy that easily falls prey to the self-serving interpretations of revolutionary actors and their political critics. I argue below that these difficulties are not unique to institutionalism and, in fact, that the recent evolution of institutionalist theory and method offers hope of a fuller understanding of what endures or fails to endure during revolutionary regime change.

\section{INSTITUTIONALISMS}

Writers who explain and critique institutionalism-even when they do not refer to the foundation work of Alexis de Tocqueville ${ }^{5}$ - often note that it has a long history, especially within political science and economics. This fact has given rise, since the 1980 s, to the term "new institutionalism." But this term is applied in complex and contradictory ways in different disciplines. ${ }^{6}$ I therefore find it easier to say what groups of institutionalists are trying to achieve than to say in a few words what they think institutions are. At the conclusion of this section I will adopt a single institutionalist perspective and proceed to a discussion of evolving Western narratives of the revolutionary era and a critique of institutionalist interpretations of the revolution and its aftermath.

The institutionalism with which Skocpol's study of revolutions is associated has deep roots in political science that were undermined by the behavioralism of the 1950s and 1960s and its incorporation of pluralist political assumptions associated with liberal states. The revival of institutionalism, partly under Skocpol's leadership, was owing not only to an increasing chorus of suspicion that aggregations of behavioral data (like the tally of votes on election day) obscured as much of the meaning of political engagement as they revealed. It was also owing to the growing conviction that social, political, and economic structures played a more decisive role in shaping community behavior than behavioralism allowed for. As one student of institutionalism puts it:

Citizens' preferences are not, as the pluralists thought, efficiently transmitted to political leaders via interest groups and political parties; instead, the representation of interests is shaped by collective actors and institutions that bear traces of their own history. Constitutions and political institutions, state structures, state interest group relations, and policy networks all structure the political process. Consequently, political demands and public policies are not shaped by the neutral and convergent exigencies of modernization. Rather, political economies - like political systems - are structured by dense interactions among economic, social, and political actors that work according to different

5 Alexis de Tocqueville, L'Ancien régime et la Révolution (Paris, 1967); and idem De la démocratie en Amerique (Paris, 1990), an early American edition of which was entitled American Institutions and Their Influence (New York, 1854). 
logics in different contexts... . Various institutional factors influence the political processes that adjudicate among conflicting interests and may hence privilege some interests at the expense of others. ${ }^{7}$

Another way to understand how institutionalists now think about institutions is to reflect on the distinction some of them make between institutions and organizations. Does it matter whether we refer to the State Duma as an institution or an organization? It depends upon which line of theory and method one follows within the disciplines of political science, sociology, and economics. To choose from among numerous, prominent examples, James G. March and Johan Olsen make little meaningful distinction, referring to "formally organized" institutions, and to "organizational factors in political life." 8

Economists such as Douglass C. North and Jack Knight, by contrast, insist upon a major theoretical and empirical difference between institutions and organizations. ${ }^{9}$ For them, organizations are formal and informal groups of "collective actors who might be subject to institutional constraint." 10 Through organizations society engages and negotiates economic, social, and political events. Firms, bureaucracies, armies, churches, communes, and families are all examples of organizations. Since organizations have physical or material components (e.g., people, perhaps buildings, budgets, technologies, material outcomes) they depend upon factors such as the demographic characteristics of their members (how densely settled or well educated, what gender, etc.), the information resources they employ during organized activities, the geographic space within which they work, and their access to community resources (such as infrastructures and more or less accessible, empowering technology). Recognizing that organizational behavior requires further explanation beyond that which would simply account for these social and material resources, North concludes that there is an impalpable, but still empirically identifiable phenomenon that he calls "institutions."

When we find people working in similar organizations with similar physical resources but with dissimilar results - for example, two similar firms producing similar products in two different countries that may chronically show quite different balance sheets-we naturally conclude that there is something operating that does not, as it were, meet the eye. For these institutionalists, it is the

\footnotetext{
${ }^{6}$ See, for example, Paul DiMaggio's summary in "The New Institutionalisms: Avenues of Collaboration," Journal of Institutional and Theoretical Economics 154 (1998):696-98.

7 Immergut, "Theoretical Core," 17.

8 James G. March and Johan P. Olsen, "The New Institutionalism: Organizational Factors in Political Life," American Political Science Review 78 (Sept. 1984):734-49. Institutions are not mentioned as an analytic category in the classic work on organizations by March and Herbert A. Simon-see Organizations (New York, 1958).

9 The distinction between institutions ("sets of rules that structure interactions among actors") and organizations will be found, inter alia, in Douglass C. North, Institutions, Institutional Change and Economic Performance (New York, 1990), 3-11, 73-82; and Jack Knight, Institutions and Social Conflict (New York, 1992), 3-4.

${ }^{10}$ Knight, Institutions and Social Conflict, 3.
} 
"institutions" that account for, or at least structure, the preferences, norms, boundaries, and cognitive characteristics which distinguish two physically similar organizations from one another. ${ }^{11}$

North's assertion that institutions are analogous to the rules of the game in a competitive team sport is both more informative and more complex than it initially seems to be. ${ }^{12}$ In order to see this it helps to understand how specific theoretical assumptions are central to mainstream, or neo-classical, economics. ${ }^{13}$ For neo-classical economists all meaningful, analyzable behavior begins with the individual whose preferences, including pervasive maximization of self-interest, are taken as given. Such a first premise leads to very stringent (but analyzable, both empirically and within the sub-discipline of decision and game theory) conclusions about social behavior.

For example, it denies that cultural, or normative, differences are significant after the conditions under which the individual participates in the market are fully understood. It is common to find propositions in this literature that assume that the values of participants in markets are given and constant, that property rights are well-defined, the costs of negotiating an agreement and of acquiring necessary information are low, and that the conditions under which competition for scarce resources is engaged are "perfect." Under such conditions, neoclassicists assert, results in the marketplace will be optimally efficient, yielding the best product for the lowest price. ${ }^{14}$

The difficulty, of course, is that these assumptions are evidently unrealistic. Even casual observation of market relations confirms both that the assumed conditions are rarely found and that truly efficient outcomes are difficult to predict. This criticism parallels the one identified above in political science. That is, the preferences of political actors are no more efficiently transmitted across organizational precincts than are those of participants in markets. ${ }^{15}$

11 For example, a recent cross-national, comparative study of economic performance concludes that institutions are more important in determining efficient performance than either natural endowments (such as climate or proximity to sea lanes) or state policies. See, William Easterly and Ross Levine, "Tropics, Germs and Crops: How Endowments Influence Economic Development," National Bureau of Economic Research, Working Paper \#9106 (Cambridge, Mass., 2002).

12 Across the past twenty five years, North has offered numerous elaborations on this definition. For example, "Institutions, Economic Growth and Freedom: an Historical Introduction," in Freedom, Democracy and Economic Welfare, M. Walker, ed. (Vancouver, 1988), 3-25; "Institutions," Journal of Economic Perspectives 5 (Winter, 1991):97-112; "Institutions and a Transaction-Cost Theory of Exchange," in Perspectives on Positive Political Economy, J. F. Alt and K. A. Shepsle, eds. (Cambridge, U.K., 1995).

13 One of the first texts to summarize this body of theory and criticize it within an historical-institutional framework is Douglass C. North, Structure and Change in Economic History (New York, 1981).

14 Ronald H. Coase, “The Problem of Social Cost," Journal of Law and Economics 3 (1960): 1-44. See North's discussion in Institutions, Institutional Change, 15.

15 Much of the literature on the "new" institutionalism in political science, sociology and economics reflects this view by searching for bases for cooperation or collaboration across institutionalist versions. See DiMaggio, "New Institutionalism: Avenues of Collaboration,” 696-98; R. Richter "Bridging Old and New Institutional Economics: Gustav Schmöller, the Leader of the 
The costs of negotiating, concluding, and executing an agreement - transaction costs - are often the result of the involvement of institutions and organizations, such as monarchs, states, churches, communes, guilds, or other controllers of information and capital resources that are not principals to the agreement. ${ }^{16}$ But in the neo-classical universe one notices that, for the sake of argument, the roles otherwise attributable to institutions are assumed away. ${ }^{17}$

North, together with other institutional theorists, originally attempted to bridge the gap between the stringency reflected in neo-classical assumptions and the world as we actually experience it - a world in which it is frequently costly to transact and where both knowledge and competition are far from perfect-by explaining that institutions are the phenomena that set boundaries, or limits, in social exchange. This distinction-that institutions are the evolved "rules of the game" - for a time separated "new" institutional economics from "old" (Veblen-Commons) institutional economics. ${ }^{18}$ North's early work on institutions is explicit about this: "Institutions are rules, enforcement characteristics of rules, and norms of behaviour that structure repeated human interaction. Hence, they limit and define the choice set of neo-classical theory. We are interested not in the institutions per se, but in their consequence for the choices individuals actually make."19

As this explanation has been extended to additional cases and circumstances-especially within the framework of comparative and historical, or evolutionary, analyses of market and productivity development and differences-North and others have been obliged to accept that institutions create not only boundary effects but that they also affect the cognition of individuals: they change the way individuals understand themselves and the world, or marketplace. Institutions, that is, contextualize transactions in ways that it is unrealistic to assume away or to imagine as merely "given and constant."20

Younger German Historical School, Seen with Neoinstitutionalists' Eyes," Journal of Institutional and Theoretical Economics 152 (1996):567-92; and Helge Peukert, "Bridging Old and New Institutional Economics: Gustav Schmöller and Douglass C. North, Seen with Oldinstitutionalists' [sic] Eyes," European Journal of Law and Economics 11 (2001):91-130.

${ }_{16}$ Paralyzing transaction costs are the empirical focus of Hernando De Soto, The Mystery of Capital. Why Capitalism Triumphs in the West and Fails Everywhere Else (New York, 2000).

17 The neoclassical theorist commonly associated with these arguments, Ronald H. Coase, does not assume zero transaction costs, only "low" ones. Nor does Coase imagine that low transaction costs in an institution-free world are necessarily the norm. In his earliest notable work, Coase devoted attention to an organization whose institutional attributes eventually were of great interest to neoclassical economics - the firm. See "The Nature of the Firm," Economica 4 (Nov. 1937):386405.

18 So-called owing to the contributions and continuing influence of Thorsten Veblen and John R. Commons. See Geoffrey M. Hodgson, "What is the Essence of Institutional Economics?" Journal of Economic Issues 36 (June 2000):326-28; and Peukert, "Bridging Old and New Institutional Economics."

19 North, "Institutions, Economic Growth and Freedom," 3.

20 David Dequech, "The Demarcation between the 'Old' and the 'New' Institutional Economics: Recent Complications," Journal of Economic Issues 36 (June 2002):565-72. Also see A. T. 
"History matters" is another much-quoted assertion of Douglass North and even a cursory examination of the recent institutionalist literature reveals that it has stimulated an enormous upsurge of interest in history. Why should this be so? Partly, it is owing to the fact that many institutional and organizational arrangements are evidently inexplicable as the products of purposive creation - they can only be explained by a narrative that tells "how they got that way." 21 In North's formulation, "history ... is largely a story of institutional evolution in which the historical performance of economies can only be understood as a part of a sequential story." 22

If we ask where the "rules of the game" that situated peasants and lords on a Russian axis of social status in the nineteenth century came from, a rehearsal of imperial edicts and statutes, a summary of incomes and expenditures, or of demographic characteristics will not explain observed and recorded behavior reflecting status relations. This set of institutions was the result of arrangements that evolved over time in innumerable combinations of purposive action, such as legislation, as well as group and individual behavior in specific organizational contexts that may have been consciously directed at goals entirely different from social status determination or that may have had no evident purpose whatever. $^{23}$

In order to explain such institutions, the argument goes, one cannot employ only scientific principles, controlling physical characteristics, or even concepts of asymmetries of power. Nor can one safely assume away changing cultural contexts or unpredicted conjunctures. One has to tell "how they got that way." This, however, is a more controversial position than it may at first seem. Such explanations have evoked a substantial literature in economics, sociology, and political science that, basically, argues that institutionalists choose from among available historical narratives in ways that simply validate their previously established theoretical positions. ${ }^{24}$ In developing solutions to this problem, Lu-

Denzau and Douglass C. North, "Shared Mental Models, Ideologies and Institutions." Kyklos 47 (1994):3-31. For a comparatively rare example from the field of Soviet and post-Soviet studies that uses neoinstitutionalist theory and contributes to it see Steven L. Solnick, Stealing the State. Control and Collapse in Soviet Institutions (Cambridge, Mass., 1998), 24-41, 218-53.

21 This is the core concept behind "path dependence." See W. Brian Arthur, "Competing Technologies, Increasing Returns, and Lock-in by Historical Events," The Economic Journal 99 (Mar. 1989):116-31; Paul A. David, "Clio and the Economics of QWERTY," American Economic Review 75 (May 1985):332-37; Avner Greif, "Cultural Beliefs and the Organization of Society: A Historical and Theoretical Reflection on Collectivist and Individualist Societies," Journal of Political Economy 102 (1994):912-50; Nathan Rosenberg, Exploring the Black Box. Technology, Economics, and History (Cambridge, U.K., 1994), 9-23, 203-31.

22 North, "Institutions," 97.

${ }^{23}$ For example, see Esther Kingston-Mann and Timothy Mixter, eds., Peasant Economy, Culture, and Politics of European Russia, 1800-1921 (Princeton, 1991); or the complex, often unpredictable status relations described in Aleksandr Nikolaevich Engelgardt's Letters from the Country, 1872-1887, Cathy A. Frierson, ed. (New York, 1993); and in Jerome Blum, The End of the Old Order in Rural Europe (Princeton, 1978).

${ }^{24}$ In sociology see the exchanges among Goldthorpe and others: John H. Goldthorpe, "The Uses 
stick, for example, emphasizes the necessity for a comprehensive knowledge of the range of relevant historical narratives - a point to which we return below. ${ }^{25}$

Understanding the importance of history to institutional studies does seem to offer insight into why institutions can be difficult to change as a consequence of purposive action. When one speaks of the history of either organizations or institutions, I suggest that the most important matter for one to have resolved is where the institutions are. If one is satisfied with the interpretation of increasing numbers of institutionalists that institutions have both rule-setting and cognition effects, then in some sense institutions must be located in the actors, the participants in social intercourse, the organizational participants. Changing the "rules of the game" through an intervention of power or ideology, or reconstructing the organizations through which actors transact, will produce some results, but not necessarily all of the results hoped for and not necessarily without the unintended consequences that follow from new, unpredicted combinations of actors, organizations, and institutions. If organizations are not reconstructed and actors are not changed, but only reeducated or rehabilitated, the likelihood of institutional change with desired and predictable outcomes in the short-run seems remote.

At this point it is helpful to recognize that many organizations, and many organizational actors, during an era of apparent radical transformation, cannot be replaced, at least in the short time that mobilized mass energy is available to revolutionary elites intent upon regime chance. ${ }^{26}$ I hypothesize that this is particularly true of organizations in certain circumstances in modern societies: of organizations that manage infrastructures in urban industrial settings and are therefore closely tied to specific technologies; of states to the extent that they depend upon such infrastructures; and of the very large organizations that manage social and economic resources which are controlled by the state itself. To the extent that state actors and state organizations are imbedded into manufacturing and commercial roles in an industrial society, moreover, institutional change will be difficult without technological change. A social revolution may mobilize masses, introduce new ideologies and norms, create chaos and destroy lives and property, but the physical remnants of the economy and its technolo-

of History in Sociology: Reflections on Some Recent Tendencies," British Journal of Sociology 42 (June 1991):211-30; idem, "The Uses of History in Sociology—A Reply," British Journal of Sociology 45 (Mar. 1994):55-57; and essays by Nicky Hart, Michael Mann, and Nicos Mouzelis in this same issue of the British Journal of Sociology that vigorously attack Goldthorpe's position; in political science, Ian S. Lustick, "History, Historiography, and Political Science: Multiple Historical Records and the Problem of Selection Bias," American Political Science Review 90, 3 (Sept. 1996):605-18; in economics, Stan J. Liebowitz and Stephen E. Margolis, Winners, Losers \& Microsoft: Competition and Antitrust in High Technology (Oakland Calif., 1999).

25 Lustick, "History, Historiography and Political Science," 615-16.

26 A point recognized at a naïve level of analysis by Lenin. See V. I. Lenin, State and Revolution (New York, 1932), 42. 
gies, and the demand for individuals who manage and many others who act as their agents, seem likely to sustain more institutional endurance than is usually claimed by revolutionaries (and, often, historians). ${ }^{27}$

Conceptually separating institutions, organizations, and actors helps one to see the difference between continuity arguments based on institutionalism and more general-but still persuasive-views, such as those advanced by Lewin. ${ }^{28}$ Institutionalism calls attention to the fact that even radical and violent attempts to change institutions will not have predictable and preferred outcomes unless it is possible to change the actors and the organizations. Focusing on specific institutions, organizations, and groups of actors also allows one to make specific comparisons between institutional and organizational arrangements before a revolutionary era and after it as well as across revolutionary experiences in different societies. Focusing on institutions and organizations, finally, helps to identify the channels through which continuities exert their influence.

\section{PERSPECTIVES ON THE REVOLUTION}

There is a large literature on the Revolution of 1917 that simply starts its narrative in the revolutionary year. This may give the impression that the relevant energies which produced revolutionary outcomes also emerged in that year or shortly before - that is, that the emergent Soviet state and society can be explained by a narrative that begins with the October Revolution. But an attractive byproduct of the experiences of the past decade has been the reconsideration of historical teaching and writing about revolutionary Russia, both in Russia and in the West. ${ }^{29}$ In an exhaustive historiographical essay, Steven Kotkin notes the "deep disillusionment and embarrassing perplexity" that ultimately characterized the mood of American students of Russia in the aftermath of $1991 .{ }^{30}$ But he nevertheless concludes his essay with a claim for the unique

27 See Knight's analysis of the endurance of informal institutions in Institutions and Social Conflict, 188-94; and Solnick's discussion of the Chinese devolution in Stealing the State, 234-40. In this study of the loyalty and defection of "street-level" agents of Soviet state bureaucracies, Solnick notes the reduced likelihood of the appropriation by defecting agents of "highly specific" assets (he uses the example of satellites: Stealing the State, 36; I would propose state-owned power plants and railways). Solnick suggests that such administrative structures endure partly owing to the inability of would-be thieves to make off with them. It is interesting to note, however, that during the 1990s international markets had increased the fungibility of certain infrastructures and raw materials (e.g., petroleum and refineries), rendering them much more vulnerable to savvy thieves than they had been during World War I and the Revolution of 1917.

${ }_{28}$ Moshe Lewin, Russia/USSR/Russia. The Drive and Drift of a Superstate (New York, 1995), $1-41,72-95$.

29 In addition to those discussed here, see also Steve Smith, "Writing the History of the Russian Revolution after the Fall of Communism," Europe-Asia Studies 46 (1994):563-78; and Barbara Walker, "(Still) Searching for a Soviet Society: Personalized Political and Economic Ties in Recent Soviet Historiography. A Review Article," Comparative Studies in Society and History 43, 3 (July 2001):631-42.

30 Stephen Kotkin, "1991 and the Russian Revolution: Sources, Conceptual Categories, Analytical Frameworks," Journal of Modern History 70 (June 1998):387. 
importance of the revolution and its aftermath: "Soviet socialism . . . is a pivotal case for understanding the matrices of social welfare and thus of early twentieth-century modernity and subjectivity that emerged transformed in the Great War. What could be called the microstructures and microprocesses of the welfare state can only be understood - in their Soviet variant too-by recourse to analytical tools finer than the blunt instruments of the totalitarian model."31

Kotkin is surely right in observing that analytic fashions which saw the first two generations of the post-revolutionary era almost entirely in the light of totalitarianism are excessively narrow and misleading. Moreover, Kotkin's interpretation of the revolution as a manifestation of twentieth-century modernity has been seconded by other scholars as a means of integrating revolutionary history into the mainstream of turn-of-the-century historiography. ${ }^{32}$ In another historiographical essay, Laura Engelstein attempted an heroic synthesis of Western historical literature on the Russian Empire since the Khrushchev era as a means of showing how perspectives have changed in the light both of theories that challenge the objectivity of the humanities and social sciences and of the Soviet vaporization. ${ }^{33}$ While her aim is to say how our views of the Empire have shifted in the wake both of unanticipated events and of changed historiography, she focuses more directly on the latter. The literature, as I read her, has been dominated by efforts to address (and refute?) Soviet interpretations and by a social (revolution from below) emphasis that gradually transformed itself into the current preoccupation with culture. She writes that, " . . . the Bolshevik triumph is now sooner seen as continuous with practices of 'modernity' already activated by the outgoing regime than as the vestige of an unsurmounted past. In this view, the Soviet outcome is not a sign of Russia's departure from the path of Western evolution, but a locally specific version of general trends." 34 But she concludes less certainly: "We may find ourselves returning to the classic question of political institutions and personalities, along with the newer one of political culture." Indeed.

William G. Rosenberg was one of the first students of the revolution to show that certain outcomes, such as the very limited success of the mixed state-capitalist market economy of the New Economic Policy (1921-1928), cannot be explained satisfactorily as consequences of $1917 .{ }^{35} \mathrm{He}$ shows, that is, that in-

31 Kotkin, "1991 and the Russian Revolution," 425.

32 For example, see essays by Nathaniel Knight, "Ethnicity, Nationality and the Masses: Narodnost' and Modernity in Imperial Russia," 41-66; Peter Holquist, "What's so Revolutionary about the Russian Revolution? State Practices and the New-Style Politics, 1914-21," 87-114; and Terry Martin, "Modernization or Neo-traditionalism? Ascribed Nationality and Soviet Primordialism," in Russian Modernity. Politics, Knowledge, Practices, David L. Hoffmann and Yanni Kotsonis, eds. (New York, 2000), 161-84.

33 Laura Engelstein, "New Thinking about the Old Empire: Post-Soviet Reflections," Russian Review 60 (Oct. 2001):487-96.

34 Engelstein, "New Thinking," 496.

35 William G. Rosenberg, "The Problem of Market Relations and the State in Revolutionary Russia," Comparative Studies in Society and History 36 (1994):356-96; idem, "Social Mediation 
stitutionalized Old Regime state roles-especially ones that emerged during World War I-limited certain revolutionary options and imposed others. He notes that, "The ubiquitous intervening and regulating state of Bolshevik Russia was not simply the construction of Leninist ideology or demonic politics: it was historically grounded in Russia's broad revolutionary conjuncture, in which the state's enmeshment in society and socio-economic process and its role as well as a site of negotiation and mediation greatly limited the prospect of political democracy ... the subsequent role of the Bolshevik state in Soviet society represented essentially a radical extension, rather than a revolutionary break, with the past." 36

A further significant characteristic of Rosenberg's analysis is his emphasis on the ways in which the state as a collection of institutions (his term) and offices was involved in "complex sets of social processes and relations," especially economic ones, shaped by cultural and other continuities. ${ }^{37}$

Rosenberg's approach deserves emphasis here for two reasons. First, it is grounded in an extended appreciation of an additional theoretical arena for interpreting the revolution: economic anthropology; second, it addresses, as social history all too rarely does, economic structures and behaviors as suchboth before and after 1917. ${ }^{38}$ But, if we understand institutions' limiting and shaping roles as linked only to exigencies imposed by the Great War, as Rosenberg and many others seem to do, we still foreclose the possible significance of longer-enduring, more deeply rooted institutions. ${ }^{39}$ In doing this we may fail to grasp the importance of state energies that survived not only to cross the Revolutionary divide, but even the collapse of the Communist regime.

THE SKOCPOL PROBLEM AND THE INSTITUTIONAL SOURCES

OF REVOLUTIONARY PROGRAMS

Consider, now, the Skocpol problem. It is perhaps unnecessary to observe that, among students of the Russian revolution, Skocpol is one of those who have taken most seriously the challenge of setting the revolution into its Old Regime context. That she and scholars with whom she worked did so influentially-

and State Construction(s)," Social History (U.K.) 19 (1994):169-88. A later, parallel argument will be found in Holquist, "What's so Revolutionary about the Russian Revolution?" For a similar argument that focuses on food management policy and institutions designed for control of the agrarian economy, see Alessandro Stanziani, L'Économie en révolution. Le cas Russe, 1870-1930 (Paris, 1998), 207-26. It is a pity that these later efforts did not benefit more fully from Rosenberg's insights.

36 Rosenberg, "Social Mediation," 187-88.

37 Ibid., 171; but see also Rosenberg, "The Problem of Market Relations."

38 Idem, "The Problem of Market Relations," 356-61.

39 The demands - strategic, technological, organizational and ethical-imposed upon state participants in World War I have collectively become a convenient touchstone not only for students of recent revolutionary and Soviet history but for critics of modernism more generally. One of the most persuasive arguments in the genre is found in James C. Scott, Seeing Like a State. How Certain Schemes to Improve the Human Condition have Failed (New Haven, 1998), 5, 97-102. 
within the framework of twentieth-century intellectuality and historical institutional theory-is beyond serious question. ${ }^{40}$ The Skocpol problem, then, is not necessarily that there are no scholars who perceive an Old Regime/New Regime axis; rather, it is that this connection is significantly underinterpreted. This underinterpretation prevents scholars from perceiving the role of institutions in shaping societies across apparent moments of discontinuity and it has been common, at least until recently, among historians of the Russian Revolution and students of the origins of Soviet economic and domestic political policies more generally. ${ }^{41}$

Skocpol's comparative analysis of social revolution in France, China, and Russia yields a complex definition of the phenomenon: "Social revolutions are rapid, basic transformations of a society's state and class structures; and they are accompanied and in part carried through by class-based revolts from below. Social revolutions are set apart from other sorts of conflicts and transformative processes above all by the combination of two coincidences: the coincidence of societal structural change with class upheaval; and the coincidence of polit-

40 And not only in historical sociology. See Robertson's assessment in "Return to History," 21.

41 There have been exceptions, of course, which explicitly address the issues of continuity and discontinuity - but, until recently, not in an attempt to assess the meaning of the revolution and very rarely within an established institutionalist-theoretic framework. The first texts that come to mind are those written or edited by Cyril E. Black: The Transformation of Russian Society: Aspects of Social Change since 1861 (Cambridge, Mass., 1960); and The Modernization of Japan and Russia (New York, 1975). The most successful transrevolutionary studies of administrative elites are undoubtedly those of John A. Armstrong: The European Administrative Elite (Princeton, 1973); "Tsarist and Soviet Elite Administrators." Slavic Review 31 (1972):1-28; "Sources of Administrative Behavior: Some Soviet and Western European Comparisons," American Political Science Review 59 (1965):643-55. The transrevolutionary evolution of economic policy and its implementation have been the focus of numerous studies including Theodore H. Von Laue, Why Lenin? Why Stalin? Why Gorbachev? (New York, 1993); Paul R. Gregory, Before Command. An Economic History of Russia from Emancipation to the First Five-Year Plan (Princeton, 1994); and Stanziani, L'Économie en révolution. Kendall Bailes traced both institutions and energies within professions along the Old Regime/New Regime axis: see his Technology and Society under Lenin and Stalin (Princeton, 1978); and Science and Russian Culture in an Age of Revolutions. V. I. Vernadsky and His Scientific School 1863-1945 (Bloomington, 1990). Similarly, Jonathan Coopersmith's study of electrification in Russia deals extensively with transrevolutionary institutional and technocratic endurance: The Electrification of Russia, 1880-1926 (Ithaca, 1992); as does Joshua A. Sanborn, Drafting the Russian Nation: Military Conscription, Total War, and Mass Politics, 1905-1925 (DeKalb Ill., 2003). The transrevolutionary endurance of specific policy alternatives and administrative procedures in rural administration is the focus of George Yaney, The Urge to Mobilize. Agrarian Reform in Russia, 1861-1930 (Urbana 1982). Studies of state administration and the Russian bureaucracy in Walter M. Pintner and Don K. Rowney's edited volume, Russian Officialdom. The Bureaucratization of Russian Society from the Seventeenth to the Twentieth Century (Chapel Hill, 1979) explicitly cross the revolutionary divide and compare pre- and post-revolutionary elite and sub-elite participation as does Don K. Rowney, Transition to Technocracy. The Structural Foundations of the Soviet Administrative State (Ithaca, 1989). The interconnections between revolutionary culture and institutions have come recently to the foreground in the work of several scholars: Katerina Clark, Petersburg, Crucible of Cultural Revolution (Cambridge, Mass. 1995); Peter Holquist, Making War, Forging Revolution: Russia's Continuum of Crisis, 1914-1921 (Cambridge, Mass. 2002); Barbara Walker, "Kruzhok Culture and the Meaning of Patronage in the Early Soviet Literary World," Contemporary European History 2, 1 (2002):107-23. 
ical with social transformation." 42 . This definition emphasizes the importance she attaches to the interconnection among class, state, and economic structures_-both domestic and international — and the sequence of revolutionary events. Within this explanatory framework, the role of the state (treated as a network of organizations) is pivotal. This is both because of the state's obvious organizational capacity to empower or to suppress agents of revolution in society as well as its less frequently recognized capacity to act autonomously from other centers of power in society. ${ }^{43}$

For all their comparative insight and generality, however, Skocpol's syntheses fail to account for what Braudel referred to as the "plurality of social time." ${ }^{44}$ Some sequences of events - say the collapse of a particular leadership coalition or the outbreak of war-are possibly unexpected and their consequences can be measured in hours, days, or a few years; but others - the transformations of economies or of demographic characteristics - are measured in generations. ${ }^{45}$ Skocpol certainly discusses sequences of events that change at different rates, but she does not always take account of which ones are rapid and which are comparatively glacial.

Of central concern in this respect are state institutions and organizations themselves. Can Skocpol possibly be right in her assertion that, during the Russian revolution, Old Regime institutions suddenly collapsed or were decisively destroyed? ${ }^{46}$ Or, that in the aftermath of revolution the Bolsheviks were forced to "rebuild state organizations suddenly, from scratch, with coercive means"? 47

Let us look more closely at one specific component of the state organizations that, Skocpol claims, the Bolsheviks were forced to reconstruct "from scratch": the super-ministerial organization called "The Council of Peoples Commissars" (Sovnarkom). What was this body and what were its historical origins? Its historian, T. H. Rigby, notes that, "Apart from its outlandish and challenging name, there seemed on the face of it little to distinguish the new "Soviet" Government from a modern "bourgeois" ministry. It consisted of a Chairman (Lenin) and fourteen other members, all but three of whom were individually responsible for specific departments of government. . .."48

In fact, this was an organization whose legal origins and structure must be traced to 1861 when Emperor Alexander II supplemented the roles of the even

42 Skocpol, States and Social Revolutions, 4.

43 Skocpol, States and Social Revolutions, 24-33.

44 Fernand Braudel, "History and the Social Sciences. The Longue Durée," in On History (Chicago, 1980), 26.

45 For an institutionalist study that takes account of these different stabilities, see Maria Ågren, “Asserting One's Rights: Swedish Property Law in the Transition from Community Law to State Law," Law and History Review 19 (Summer, 2001): esp. 20-29.

46 Skocpol, States and Social Revolutions, 210-21.

47 Ibid., 283.

48 T. H. Rigby, Lenin's Government. SOVNARKOM, 1917-1922 (Cambridge, U.K. 1979), $2-3$. 
longer-lived Committee of Ministers with those of a new "Council of Ministers." ${ }^{49}$ More significantly, the type of organizational structure over which the commissars presided in 1917 can be traced straightforwardly to the era of Alexander I and the year 1802. There were good reasons why the revolutionary regime sought to obscure these historical connections and why it made use of ample and increasing resources at its disposal to do so. What is much less clear is why Skocpol should not have attributed greater importance to these connections in a study of state-revolutionary relations.

The decision, made in October 1917, by Lenin and supported by his closest Bolshevik associates to continue this body was neither casual nor provisional. As Rigby observes: “ . . . the Soviet government was heir to a continental bureaucratic tradition which in Russia, no less than in France or Germany, linked decision-making with ample documentation, formal rules and secretarial support staff. In fact models for the machinery and procedures adopted by the Sovnarkom had already been provided by its predecessors in the Tsarist and Provisional Governments." 50 Rigby takes pains to show that this administrative system directly competed for monopoly power with those being constructed by provincial, regional, and local political bodies such as soviets and local commissariats. In time, however, it was the centrist, statist model that came to dominate, a model that forced regional and local organizations to transact both political power arrangements and fiscal allocations through the administrative center rather than independently, federally, or within regional groupings.

Sovnarkom was the same centrist system of political and fiscal management that the Old Regime had used. Contrary to Skocpol's assertion, this was not an organization the Bolsheviks were forced to build "from scratch." Nor was it an institutional arrangement or cluster of organizations that had emerged out of wartime exigency. It had deep roots in the Russian political and administrative past that had less to do with an emergent modernity than with the accumulation of small successes in a century-long series of trials and errors. The preservation of these centrist institutional characteristics and the organizations within which they were to be found (i.e., the commissariats and the Sovnarkom) established them as the standard for all territorially distributed systems in the Soviet Union, a point to which we return below. This institutional survival is the outcome that much of institutional theory predicts. Pervasive and broadly distributed organizational structures tend to endure and they change but slowly. ${ }^{51}$

Given the stress Skocpol places on state roles in States and Social Revolutions and elsewhere, her underinterpretation of the role of state-based organizations

49 Legislation confirming the Council is found in Polnoe sobranie zakonov, II, 36, no. 27619; the origins of the Committee of Ministers and the ministerial system itself reach back to 1802 (Polnoe sobranie zakonov, I, 27, no. 20406) and, we might note, forward to the present.

50 Rigby, Lenin's Government, 224.

51 For example, see North's arguments in Institutions, Institutional Change, 3-10; "A Transaction Cost Theory of Politics," 355-67; "Institutions," 102-4; and Knight, Institutions and Social Conflict, 171-208. 
across the revolutionary divide is surprising. She lays great emphasis on the size, energy, and egalitarian character of post-revolutionary and, especially, Stalinist administrative bodies. ${ }^{52}$ She also attaches great importance to the coercive force of the VCheKa political police and to the aggressive behavior of cadres within the Bolshevik party. ${ }^{53}$ But enduring state organizations, such as Sovnarkom, and the roles played by actors who began their careers in tsarist service and continued them under the Bolsheviks are absent as explanatory factors.

Skocpol considers the possibility that the rapidly growing state presence in the 1920s and 1930s was a consequence of the institutional momentum developed after the Great Reforms of the 1860 s and rejects it. ${ }^{54}$ Her judgment was evidently based on a partial assessment of numbers of personnel. ${ }^{55} \mathrm{Had}$ she looked more closely at the origins of the scope and authority of new state organizations, she would have seen a much more explosive growth pattern throughout the nineteenth century and especially during the era of intensive, state-stimulated industrialization between 1885 and 1900.

In the nineteenth century the entire state apparatus developed with relentless energy. Between 1800 and 1850 the imperial population increased by roughly 67 percent; employment in the civil state bureaucracy rose 300 percent. Between 1850 and 1900, population rose by a further 85 percent; employment in the civil bureaucracy rose more than 500 percent, exceeding 380,000 men and women. ${ }^{56}$ The ministries, chief administrations, clerkships, police organs, and procuracies of the civil bureaucracy were the single largest consumer of the output of imperial Russia's universities and technical schools. ${ }^{57}$ Consider, finally, the developing state roles in control over the national economy, that I hypothesized earlier might become particularly resistant to short-term change. More than 100 new agencies were created in the last third of the nineteenth century by the Imperial government for overseeing, taxing, licensing, or in some other way managing aspects of the developing industrial and commercial economy. ${ }^{58}$

Skocpol concludes that the Stalinist state was much more firmly in control

52 Skocpol, States and Social Revolutions, 206-33.

53 Ibid., 216-17.

54 Ibid., 226-28.

55 Relying, apparently, on an essay by Alf Edeen, "The Civil Service: Its Composition and Status," in Cyril E. Black, ed. The Transformation of Russian Society, 274-91.

56 Population data from the first half of the nineteenth century: V. M. Kabuzan, Narodonaselenie Rossii v XVIII-pervoi polovine XIX v. (Moscow, 1963); the second half of the nineteenth century: A. G. Rashin, Naselenie Rossii za 100 let (1811-1913) (Moscow, 1956), 20. Bureaucracy data: N. P. Eroshkin, Istoriia gosudarstvennykh uchrezhdennii dorevoliutsionnoi Rossii, $3 \mathrm{~d}$ ed. (Moscow, 1983 [1st ed. 1965]), 140-41, 194-95.

57 Arcadius Kahan, "Social Structure, Public Policy, and the Development of Education," in Russian Economic History. The Nineteenth Century, Roger Weiss, ed. (Chicago, 1989), 174, 17778. For an interesting study of how officialdom thought of education as a tool of state policy see idem, "Russian Scholars and Statesmen on Education as an Investment," in Russian Economic History, 191-98.

58 Don K. Rowney, "The Autonomous State and Economic Development: Industrial Administration in Russia, 1880-1920." Journal of Policy History 7 (1995):226-61. 
of a broader swath of Soviet society and territory in, say, 1935 than was the Tsarist state in, say, 1900. Undoubtedly this is true just as it is true that Stalinist civil and economic administrations were much larger than their Imperial predecessors - especially if one includes industrial management organizations. ${ }^{59}$ But if one were to extend the comparison by asking whether the state had more secure access to economic and social control resources and more reliable, predictive control over developing infrastructures in 1900 than at the time of the Crimean War (1854-1855), the answer surely would be yes again. It was in the aftermath of that disastrous war and during the Great Reforms of the 1860s that the state intensified its relentless penetration into the economic and social life of the "undergoverned" territories of the Russian empire. ${ }^{60}$

Skocpol does reach back into Russian history for explanations of certain important and enduring revolutionary phenomena. She argues that, “ . . differences in revolutionary outcomes can in significant part be attributed to the influence of differences in the sociopolitical structures and patterns of economic development of the pre-Revolutionary societies.... Old regime structures helped to shape specific variations in the revolutionary outcomes not merely by surviving, but because they set different limits for successful revolutionary efforts for gaining state power and for using that power once consolidated to promote national development." 61 Class relations, she asserts, were ultimately altered fundamentally in Russia by misguided state policies during the Emancipation and post-Emancipation eras (say, the reign of Alexander II, 18551881). The overall effect of the post-Emancipation measures, in her view, was to enhance peasants' collective handling of their own local political affairs and thus to render villages more autonomous and unified against outsiders:

How could there have been a set of conditions more conducive to agrarian revolution? A nobility in economic and political decline maintained, nevertheless, a foothold in the countryside - tied to the peasants by baldly exploitative and functionless rentier relations. Meanwhile, the collective institutions and political independence of the peasant communities had been strengthened, while the peasants were burdened with heavier outsider demands to be met with unchanged methods of production. . . . All that was necessary to ensure a general conflagration was the failure of coercive controls. That happened temporarily in 1905, and again - this time irreversibly —in 1917. Both times the occasion was war and defeat for the Imperial military. ${ }^{62}$

59 Don K. Rowney, "The Scope, Authority and Personnel of the New Industrial Commissariats in Historical Context," in Social Dimensions of Soviet Industrialization, William G. Rosenberg and Lewis H. Siegelbaum, eds. (Bloomington, Ind., 1993), 124-45.

60 "Undergoverned" is the way Starr characterized Russia's provinces before the Great Reforms, giving the impression that this was unique to Russia at the time. See S. Frederick Starr, Decentralization and Self-government in Russia, 1830-70 (Princeton, 1972), ch. 1. Undergovernment is a state-society arrangement in which the state is responsible for few services apart from maintaining the ruling elite, military defense, and diplomatic relations. It was a system characteristic not only in pre-Reform Russia but in other pre-modern states including those in Europe.

61 Theda Skocpol, "Old Regime Legacies and Communist Revolution in Russia and China," Social Forces 55 (1976-1977):284.

${ }^{62}$ Skocpol, States and Social Revolutions, 132-33. 
One could object to many of these generalizations. Had peasant "collective institutions" and "political independence" actually been measurably strengthened at the turn of the century? Were peasants burdened with "heavier outsider demands"? These were and remain controversial issues among social and economic historians. It is not clear that peasant standards of living — at least considered across the whole of European Russia-were significantly worse in 1900 than in 1860 any more than it is certain that taxation levels were higher (when income is taken into account) or that the communes were stronger. Many of these are arguments that Geroid Tanquery Robinson deployed in his 1961 study, Rural Russia Under the Old Regime, upon which Skocpol seems to have drawn. ${ }^{63}$ And, while she did rely upon more recent social histories of the peasantry, Skocpol ignored much of the array of studies in economic history that were available even in the 1970s. ${ }^{64}$

Skocpol's interpretation of the state's responsibility for these outcomes apparently rests also upon her reading of Alexander Gerschenkron. ${ }^{65}$ But his interpretations have been attacked more than once and, in any case, they suffer from the major difficulty that he relies entirely on national, macro-economic data which conceal regional variations that became more-not less-important during the advance of industrialization before 1914. These details and their connection to Old Regime policies are nevertheless essential to Skocpol's general thesis: that lower-class disaffection, arising from the behavior of mismanaged and outdated organizations, resulted in political activism in 1905 and 1917 that first undermined, and then permanently destroyed, nineteenth-century Russian property structures and, with them, the class hierarchies that depended upon them. And, lying at the source of these cataclysmic changes, were the misguided reforms and social policies of Alexander II and his successors.

Skocpol's analysis of the sources of fundamentally altered class relations after 1917 seems less an empirically based explanation of how Old Regime "structures helped to shape specific variations in revolutionary outcomes" than a traditional statement of tsarist policy failings, shaped to support her notions of destructive tensions between class structures and political systems. It shares

63 Geroid Tanquary Robinson, Rural Russia under the Old Regime: A History of the LandlordPeasant World and a Prologue to the Peasant Revolution of 1917 (New York, 1961). For extended critiques, see Stephen G. Wheatcroft, "Crises and the Condition of the Peasantry in Late Imperial Russia," in Peasant Economy, Culture, and Politics of European Russia, 1800-1921, Esther Kingston-Mann and Timothy Mixter, eds. (Princeton, 1991), 128-72; Gregory, Before Command, 37-54.

64 For example, Paul R. Gregory, "Economic Growth and Cultural Change in Tsarist Russia: A Case of Modern Economic Growth?" Soviet Studies 23 (Jan. 1972); and "Some Empirical Comments on the Theory of Relative Backwardness: the Russian Case," Economic Development and Cultural Change 22 (July 1974):654-65.

65 Alexander Gerschenkron, "Agrarian Policies and Industrialization, Russia 1861-1917," in The Cambridge Economic History of Europe, vol. 6, H. J. Habakkuk and M. Postan, eds. (Cambridge, U.K. 1965); idem, Economic Backwardness in Historical Perspective (Cambridge, 1962), $706-800$. 
much in common with histories that explain the onset of revolution principally in terms of the failings of the Old Regime, or that simply treat the Old Regime as a black box that, a-priori, accounts for the twentieth-century slide into chaos. As such, this institutionalist analysis fails to take account of additional structural factors that could - and, in the view of some institutional analysts, should-be included. ${ }^{66}$

\section{STRUCTURAL COMPONENTS FOR STRATEGIC ECONOMIC CONTROL}

Between 1917 and the early 1920s the organizational and institutional structure that the Soviet post-revolutionary regime would finally adopt was far from clear and, during those years, institutional continuities were not as evident as they would later be. Note, nevertheless, that elite weakness in certain circumstances (such as the blundering incompetence and policy incoherence described by Gatrell, Lih, and Yaney ${ }^{67}$ ), did not necessarily mean that the organizations and institutions which they served would entirely disappear, or that, under the right circumstances, their participants would not return and they would not be potent and effective instruments for imposing institutional constraints (as detailed, for example, in the case of the Commissariat of Agriculture by Heinzen ${ }^{68}$ ) on social transactions at another time. The 1914-1921 era, especially in the more intensely industrialized provinces of European Russia, the Baltic, and Poland, witnessed a rapid unraveling of infrastructural networks such as rail, electricity, and commodity distribution. Paralysis of formal state organizations owing to the departure or incapacitation of qualified staff may have been the cause of some of this unraveling; infrastructure oversight, after all, became a major state responsibility from the mid-nineteenth century forward. But it is also evident, as Lih has shown, that the physical destruction and deterioration of infrastructure contributed to organizational paralysis and that the reconstitution of one depended upon, and could be predicted from, the reconstruction of the other. ${ }^{69}$

The Supreme Council of the National Economy (VSNKh) was one of the first new administrative entities to appear. But it was created in the midst of a revolutionary fog of novel entities such as hundreds of soviets, worker control organizations, and citizen and military committees. Some of these endured in one form or another and others did not. VSNKh's organizational prowess waxed and waned during the 1920s. By the end of the decade, however, it was a huge,

66 For example, Immergut, "Theoretical Core," 22-29; Robertson, "Return to History," 26-29.

67 Peter Gatrell, A Whole Empire Walking: Refugees in Russia during World War I (Bloomington, Ind., 1999), Lars T. Lih, Bread and Authority in Russia, 1914-1921 (Berkeley 1990); and Yaney, The Urge to Mobilize.

68 See James W. Heinzen's study of the survival and resurgence of an "institutional sub-culture," in the Commissariat of Agriculture: Inventing a Soviet Countryside. State Power and the Transformation of Rural Russia, 1917-1929 (Pittsburgh, 2004), esp. 91-135. Heinzen's is a detailed study of the role of experts, carried over from the Old Regime, in the evolution of post-revolutionary administrative policy and structure.

69 Lih, Bread and Authority, 231-73, passim. 
powerful, centralized organization that was soon broken into three (and, subsequently, numerous) similarly centralized state industrial management bureaucracies during the forced industrialization of the First Five Year Plan. ${ }^{70}$

Other organizations, not similarly dependent upon infrastructures and developing industrial technologies (although they seemed quite vigorous for months or years), ultimately disappeared or lost their organizational coherence and their long-term influence on policy and social behavior. For example, as I read Heinzen's narrative of the reemergence of the Commissariat of Agriculture, the influx of non-party specialists in the new political environment of the early 1920s stimulated a growth both in size and influence of the organization that were unprecedented in the history of Russian agricultural administration. Heinzen refers to the energy that wrought this outcome as a "politics of expertise." ${ }^{11}$ Nevertheless, by the end of the twenties Stalinist decisions to force collectivization dramatically and rapidly changed both the policy and organizational environments in which the Commissariat operated. An organization and institution that had managed to cross the revolutionary divide was replaced by new entities and its personnel were purged. ${ }^{72}$ This extinction of the Commissariat's social and economic roles and the political, if not physical, annihilation of much of its staff did, in this case, create the conditions in which the Stalinist state could, in Skocpol's terms, "rebuild state organizations suddenly, from scratch, with coercive means." Similar narratives emerge from the close analysis of the "de-professionalization" of other organizations by Alain Blum and Martine Mespoulet. ${ }^{73}$ I argue that VSNKh and its successor organizations in the 1930s were better able to defer, or in some cases avoid altogether, this fate owing to the state's relatively inelastic dependence upon the technical skills and experience of their staffs, and the structures and operational strategies they employed. ${ }^{74}$

The Bolsheviks represented themselves and the regime they were creating as sharply discontinuous with the past even though this was contradicted by both logic and the empirical data their own surveys produced. The logic came from the fact that, outside the old elites and their direct subordinates, few citizens had

70 Rowney, "New Industrial Commissariats," 131-43.

71 Heinzen, Inventing a Soviet Countryside, 104-19.

72 Ibid., 185-219.

73 Alain Blum and Martine Mespoulet, L'Anarchie bureaucratique. Statistique et pouvoir sous Staline (Paris, 2003); and Martine Mespoulet, Statistique et révolution en Russie. Un compromise impossible (1880-1930) (Rennes, 2001).

74 The successful defense of industrial-technical specialists in VSNKh and its successor organizations - even in the midst of storms of political criticism — was a commonplace of Soviet politics throughout NEP and the early Five Year Plan era. For example, see Sheila Fitzpatrick, "Ordzhonikidze's Takeover of VSNKh: A Case Study in Bureaucratic Politics," Soviet Studies 37, 2 (1985):153-72; E. H. Carr and Robert W. Davies, A History of Soviet Russia. Foundations of a Planned Economy (London, 1969), vol. 1, "The Specialists," 574-604; Heinzen, Inventing a Soviet Countryside, 107. Generally, O. V. Khlevniuk, In Stalin's Shadow: The Career of "Sergo” Ordzhonikidze (Armonk, N.Y., 1995); and G. K. Ordzhonikidze, Stat'i i rechi (Moscow, 1957), esp. vol. 2, 1926-1937. 
the training - even the literary and ciphering skills - needed to carry on the clerical and managerial roles of state service. This inevitably meant that state agencies relied to some extent on holdovers from the Old Regime. ${ }^{75}$ While this was clearly the case across every profession, some were more vulnerable to political intrusion than others. In the threatening conditions of the post-revolutionary era, there was a strong motivation for individuals who were somehow formally associated with the Old Regime to conceal this fact, and so the findings of the numerous surveys conducted by the New Regime that attest to the enduring roles of Old Regime holdovers are extraordinary. As Blum and Mespoulet show, the survey methods and findings themselves became a source of political vulnerability for the statisticians who gathered the data. ${ }^{76}$ In partial response to this state of affairs, as Figes and Kolonitskii show, New Regime officials in both state and Communist Party offices supported and contributed to the conceptual revolution by "desacralizing" the monarchy, associating their revolution with the French Revolution of 1789, substituting new images of power and leadership for the now contemptible old ones, and, above all, aggressively substituting new organizational and policy images, titles, and language for those of the Old Regime. ${ }^{77}$

Apart from the important exception of the Communist Party itself, if any of the novel creations of the revolution can be said to have produced long-lasting and significant consequences that justify claims of the revolutionaries that they were creating a New Regime within a new world, it must be VSNKh. Its impact on the national economy together with its utility to the early Stalinist era as an instrument of social and economic control must surely qualify it as an organization whose institutional structures shaped the world of the twentieth century.

The questions that remain, however, are how novel was it? And what, if anything, did VSNKh owe to Old Regime legacies as opposed to the Bolshevik vision of a new society that demanded new organizations and institutions? Did the Bolsheviks create it 'from scratch,' or was it a product of policies, organizational parameters, and the work of political elites that owed significant debts to the Old Regime and that, therefore, pre-dated the Revolution of 1917 and even World War I?

During the 1914-1918 war, as an increasing number of historians now agree,

75 Many scholars attest to this fact: Yaney, The Urge to Mobilize; A. G. Kavtaradze, Voennye spetsialisy na sluzhbe respubliki sovetov, 1917-1920 (Moscow, 1988); Daniel T. Orlovsky, "Professionalism in the Ministerial Bureaucracy," in Russia's Missing Middle Class. The Professions in Russian History, Harley D. Balzer, ed. (Armonk, N.Y., 1996), 267-92, esp. 286-92; James W. Heinzen, "Alien Personnel and the Soviet State: The People's Commissariat of Agriculture under the Proletarian Dictatorship, 1918-1929," Slavic Review 56, 1 (Spring 1997):73-100.

76 Blum and Mespoulet, L'Anarchie bureaucratique, 95-165.

77 Orlando Figes and Boris Kolonitskii, Interpreting the Russian Revolution. The Language and Symbols of 1917 (New Haven, 1999): on the monarchy, 13-18; on association with the language and symbols of the French Revolution of 1789, 30-37; on titles, 57-61; on language more broad1y, 107-26, passim. 
the state attained a new level of involvement in the national economy in the sense that state elites took steps to integrate and manage the national economy in large commercial and manufacturing blocs. The first steps, taken in the spring of 1915, were designed to be implemented by the Ministries of Ways of Communication and Trade and Industry. They focused not on the traditional concerns of a Russian government at war-manpower and finance-but on control over transport and raw materials. ${ }^{78}$ In June 1915, the first of a series of coordinating boards appeared under the presidency of the Minister of War. This Special Advisory Council included representatives of several other ministries, of the Duma, and of trade and manufacturing enterprises, and was subordinate only to the tsar', a meaningless stricture that essentially conferred autonomy. ${ }^{79}$ It was the first body to be given power to control the operations of groups of firms either by preemptive orders or by requisition. ${ }^{80}$ In August 1915 a quartet of new Special Advisory Councils, replacing the one created in the spring, received broad powers to coordinate measures in the national economy to support national defense, provide fuel for state and military operations, control the food supply, and transport of these items and others deemed essential to national defense. Again, these bodies included representatives from various segments of state and private industry under the presidency of officials possessing extraordinary executive power. These organizations were called "state institutions of the highest order" answerable, again, only to the tsar'. 81

The impulse to create these organizations was doubtless inspired by a desperate need to master a war-time crisis and, in this respect, Russia imitated Germany and other warring states. This is the explanation that Siegelbaum offers and it is plausible. ${ }^{82}$ However, if one looks at the pre-war period, there is reason to see these wartime approaches to the problem of procurement as extensions of a state strategies from a still earlier era.

Beginning as early as the 1880 s, the state either acceded to or encouraged the consolidation of increasingly large firms into syndicates and trusts for the main purpose of manipulating markets. ${ }^{83}$ By 1914, there were some 150 of these syn-

78 Sobranie uzakoneniia, st. 865 (31 Mar. 1915), st. 1091 (2 May 1915), st. 1169 (19 May 1915) and st. 1215 (29 May 1915).

79 Without offering much persuasive evidence, Yaney attaches greater importance to this detail, seeing it as resulting in bypassing existing state organizations and contributing to what he calls "line-over-staff" (that is, agent-dominated ad hoc) procedures (Urge to Mobilize, 421-26).

80 Sobraniie uzakoneniia, st. 1280 (7 June 1915).

81 See the summary in Pravitel'stvennyi vestnik, no. 182 (Wed., 19 Aug./1 Sept. 1915), 1, cols. 2,3 . There are several first-hand accounts of the emergence of these entities. For example, Iakov M. Bukshpan, Voenno-khoziastvennaia politika. Formy i organy regulirovaniia narodnogo khoziastva za vremia mirovoi voiny 1914-1918 gg. (Moscow, 1929), 251-459. Note the bibliographic references on 247, 258-59, 529.

82 Lewis H. Siegelbaum, The Politics of Industrial Mobilization in Russia, 1914-1917: A Study of the War-Industry Committees (New York, 1983).

83 V. Ia. Laverychev, Gosudarstvo i monopolii v dorevoliutsionnoi Rossii (Moscow, 1982); idem, "Zarozhdenie gosudarstvenno-monopolisticheskikh tendentsii v rossiskoi ekonomike kontsa XIX v,” Istoricheskie Zapiski Akademii Nauk SSSR 109 (1983):95-128. 
dicates across fifty industries. ${ }^{84}$ It was these 150 syndicates that were marshaled into main administrations for supply and distribution ( lavki), first under the tsarist government's Central War Industries Committee (1915) and Special Council for National Defense (1916), and subsequently under the Bolsheviks' VSNKh, between 1917 and $1921 .{ }^{85}$

It seems indisputable that the existence of pre-war trusts mattered when it came to creating the administrative foundations for a centralized plan apparatus. On the one hand, tsarist era glavki served as the administrative foundation for state supply-demand coordination in early post-Revolutionary days, so much so that the early glavki were sometimes seen by VSNKh as competitors for managerial control of large manufacturing. ${ }^{86}$ On the other hand, the carryover of staff from the tsarist bureaucracies was large enough to be a source of concern to Bolshevik senior leadership owing to differences in policy objectives and the suspicion that these staffs were simply not trustworthy by revolutionary standards. ${ }^{87}$

In her study of the transfer of economic organizations across the divide, Malle describes the claim by a senior Bolshevik official, Iu. Larin, that he arbitrarily and personally authorized the creation of glavki as a source of "the epic distortion of post-revolutionary records." ${ }^{88}$ Remington, too, identifies areas in which "without a blueprint" the Bolsheviks subsumed such organizations directly from the Old Regime. He includes not only the glavki, but also territorial administration, and State Control, the organization that won the contest with that revolutionary novelty, Rabkrin, (Workers' and Peasants' Inspection) in 1918 for fiscal oversight of state operations. ${ }^{89}$ By contrast, the creation of a central control apparatus for relatively decentralized, longer-established industries such as textiles was slower than that of industries such as mining, coal, and sugar, where comparatively integrated trusts had already been established, some as early as the 1880 s. ${ }^{90}$

Even without considering the Russian state's special relationship to the na-

84 Lev Borisovich Kafengauz, "Sindikaty v Rossii," in idem, Evoliutsiia promyshlennogo proizvodstva Rossii (posledniaia tret' XIX v.-30-e gody XX v.) (Moscow, 1994), 625-28.

85 Malle, Economic Organization, 218-19; note, however, that Malle traces the history of trusts and syndicates only to the post-1905 era in contrast to Kafengauz, who followed their origins to the 1880s ("Syndikaty v Rossii," 626), and to E. N. Gorodetskii, Rozhdenie sovetskogo gosudarstva, 1917-1918 gg. (Moscow, 1987).

86 Malle, Economic Organization, 219-21.

87 Ibid., 223-24. See also Heinzen, Inventing a Soviet Countryside, 185-219, passim; Carr and Davies, Foundations of a Planned Economy, 574-604; Rowney, Transition to Technocracy, 10923.

88 Malle, Economic Organization, 223-34.

89 Thomas F. Remington, Building Socialism in Bolshevik Russia. Ideology and Industrial Organization, 1917-1921 (Pittsburgh, 1984), 44-45, 48, 67, 74-75, 180-81.

90 William Benjamin Husband, "The Nationalization of the Textile Industry of Soviet Russia, 1917-1920.” Ph.D. dissertation, Princeton University, 1984, 256-304. Also see Alec Nove's comments in An Economic History of the U.S.S.R. (New York, 1972), 52; and Malle, Economic Organization, 224. 
tional economy, any effort to characterize the origins of the Soviet centralized system of economic control and its associated administrative apparatus raises a critical question: why did the Bolsheviks, whose political values were shaped by an ideology that depicted the state, its officials, and its organizations as tools of coercion and exploitation, choose to employ a strategy of development that required a strong-state foundation?

The increasingly common, but hardly novel, explanation, as we have seen, is that Bolsheviks were pursuing initiatives that combined socialist ideology and wartime exigencies. This "technocratic response" to World War I (in the phrase employed some years ago by Alchon ${ }^{91}$ ) is the broadly plausible explanation of the rise of the "mobilization state" offered by Remington and extended considerably in the work of Porter. ${ }^{92}$ This seems a likely necessary part of the explanation for the Bolshevik acceptance of the strong state; but it is not sufficient to account for the long-term endurance of the policy.

I argue that the "state" with which the Bolsheviks were working was largely the organizational and institutional apparatus that was already in existence before 1914. Associated with that apparatus were institutional sources that gave substance and continuity both to tsarist and Soviet wartime mobilization strategies. Without these, the fate of the wartime mobilization strategy would presumably have been the same in Russia as it was in Germany or Great Britainthe return to peacetime, more decentralized modes of economic operation, and the emergence of post-war political issues that eventually undermined public support for mobilization. This is the outcome that, radicalized, the proponents of the policies of what came to be known as War Communism (1917-1921) attempted to achieve - a decentralization of authority and disaggregation of official control so extreme that urban and industrial organization nearly disintegrated. That this was not the ultimate outcome in Russia, and that War Communism was succeeded during the New Economic Policy (1921-1927) by reconstruction of centrist authority over much of the economy, state territory, and state offices, argues that wartime mobilization worked in conjunction with longer-lived, institutionalized social behavior.

\section{TERRITORIAL ADMINISTRATION}

There are other aspects of the Russian state organizational and institutional structures that help one to understand the system's energy and endurance. The outcome of the Civil War and the negotiations that in 1922 produced the Union of Soviet Socialist Republics were the results of choices by state elites on the

91 Guy Alchon, The Invisible Hand of Planning: Capitalism, Social Science and the State in the 1920s (Princeton, 1985), 21-50.

92 Remington, Building Socialism, 3-22; Bruce D. Porter, War and the Rise of the State. The Military Foundations of Modern Politics (New York, 1994). Also Yaney, Urge to Mobilize, 44755; and Charles S. Maier, "Between Taylorism and Technocracy: European Ideologies and the Vision of Industrial Productivity in the 1920s," Journal of Contemporary History 5, 2 (1970):27-61. 
order of the choices, say, not to abolish serfdom in 1815 or to do so in 1861 . The vast bulk of the imperial territorial structure was divided and unequally distributed across European, Caucasian, and Asiatic Russia. The Siberian, Asiatic, and Caucasian portions were overseen in the nineteenth century by eight enormous military governor-generalships and other purpose-made organizations such as special railroad and civil administration organizations reporting directly to the central government. ${ }^{93}$ Although much, but not all, ${ }^{94}$ of the historical literature understandably focuses on the Civil War as an era of competing strategies for survival of the revolution, it is clear that the revolution also continued specific strategies to maintain the Old Regime's geopolitical structure. As a consequence, the strong state role was historically built into both Russian and Soviet political geography in the way it would have been in Great Britain if, instead of being located thousands of miles distant, British Africa and India had been physically connected to the British Isles. ${ }^{95}$

Density in the most sparsely populated provinces of European Russia was slightly greater than that of the most densely populated districts in the east. This meant that Siberia and Central Asia presented very different problems in territorial administration from those of European Russia. There were no large, ethnically Russian or Westernized communities to which regional and local administration could be entrusted. This fact enhanced the role of the tsarist central state administration which, unsurprisingly, chose to operate through the medium of military discipline and the cooptation of local traditional elites. Distances were very great. The east was more than twice the enormous size of European Russia. Any decision to invest in infrastructure, such as railways or electrical networks, necessarily involved the central government at the highest levels owing to closely linked budgetary, organizational, and military-strategic issues. ${ }^{96}$ This political geography was sufficiently well established in the eighteenth and nineteenth centuries that it gave rise to the large number of organizations responsible for its administration and exploitation, all of which depended upon robust central state power.

In the relatively developed portions of European Russia, economic structure, as it emerged over time, also gave the state a unique and controlling role. It was the state's administrative organizations-the Ministry of Internal Affairs, the

93 Erik Amburger, Geschichte der Behördenorganisation Russlands von Peter dem Grossen bis 1917 (Leiden, 1966), 399-424.

94 For an example that views it primarily as empire re-building, see Richard Pipes, The Formation of the Soviet Union. Rev. ed. (New York, 1968).

95 For a parallel discussion see William R. Thompson and Gary Zuk, "World Power and the Strategic Trop of Territorial Commitments," International Studies Quarterly 30 (1986):249-67; but see also North's discussion of the institutional determinants of the state's size and structure in Structure and Change, 20-32.

96 Coopersmith, Electrification. Also see Fiona Hill and Clifford Gaddy, The Siberian Curse. How Communist Planners Left Russia Out in the Cold (Washington, D.C., 2003). The Hill and Gaddy work gives little discussion to the tsarist imperial "legacy." It dwells at length, however, on the inefficiencies and irrationalities of Soviet efforts to legitimize control of Siberia. 
Ministry of Finances and, later, the Ministry of Ways of Communication and the Ministry of Trade and Industry - that presided at the nexus of labor oversight, provision of finance capital, tariff protection, and the creation both of corporations and of scores of monopolies and trusts, not only in the early twentieth century, but across the entire preceding generation of state-sponsored industrialization. ${ }^{97}$

Each of these components of the economy could have been conceived without these state organizations and their officials. But in fact, in Russia they all engaged (without necessarily cooperating) with one another at the top, policydevelopment level and at the points where they contacted society under the supervision of a rapidly increasing number of state organizations. As noted above, the increase in agencies responsible for overseeing, licensing, and otherwise controlling economic affairs was particularly great between 1861 and the turn of the century, and the entire state apparatus developed with increasing breadth and momentum across the whole nineteenth century. Owing to the state's voracious appetite for technically and professionally educated graduates, if the revolution needed to tap the resources of educated Russia, it was obliged to turn to the bureaucracy and to accept its centralized, hierarchical institutional habits.

Territorial administration offers but one illustration of the outcome of Lenin's decision to organize his government within the structural and, by default, the rule-making framework of the tsarist ministerial system. Post-Civil War reintegration of non-Russian territories was accomplished on the tsarist political model for practical reasons: it may not have been the most desirable set of rules, but it was the set of rules that worked owing to already existing organizational and institutional arrangements. It worked owing to the continuation of programs for structuring commercial and manufacturing components of the national economy under central state authority. And it worked for other reasons, fundamentally institutional and organizational. These included the processes engaged in the reconstruction of pre-existing technical infrastructures (such as the rail, telegraph, and electrical nets) and the commitment to continue and extend use of state organizations to exploit them; the survival of administrative and public presuppositions about the nature of state rule-making power and responsibility; and the survival of understandings of the hierarchical nature of administrative authority. The latter two constitute the cognitive and contextualizing dimensions of institutionalism mentioned earlier. ${ }^{98}$

The return to centrist institutional arrangements established them as the "rules of the game" for all post-revolutionary, territorially distributed systems,

97 North, in an early work, goes so far as to equate these and other state "services" with "the underlying rules of the game" that constitute state institutions. See Structure and Change, 24.

98 Hill and Gaddy, Siberian Curse, 26-56. There is also a body of literature which argues that the reconstruction of imperial boundaries owed something to Bolshevik efforts to co-opt support from nationalist segments of the post-revolutionary political environment and from individuals such as Nikolai Ustrailov. Among others see Roman Szporluk, Communism and Nationalism. Karl Marx versus Friedrich List (New York, 1988); and Mikhail Agursky, Ideologiia national-bol'shevizma (Paris, 1980). 
including the Communist Party, GOSPLAN, and the commissariats that would eventually direct industry and commerce. The endurance of this institutional network enforced the processing of budgetary, personnel, and strategic development decisions through the center-an extreme, asymmetrical distribution of authority and information. In this context, War Communism should be understood as a determined effort to displace centrist institutions with a far less hierarchical, less asymmetrical set of rules. Its failure to do so while the state survived is unremarkable in institutionalist perspective-an interpretation that makes Skocpol's analysis seem the more extraordinary.

Finally, keep in mind that with the passage of time Soviet elites adopted many additional programs and practices that depended upon a strong center. For ambitious political leaders who wanted radical and rapid social change, a powerful central executive obviously offered attractive alternatives to endless negotiation with local soviets, workers' trade unions, or even Rabkrin.

\section{MASTERING THE NARRATIVE VERSUS THE AMBITION TO CONTROL}

Every revolutionary regime presumably needs to create space, a cordon sanitaire, between itself and the Old Regime. That space offers scope for the New Regime to claim and amplify its differences from the Old Regime, an essential step in legitimization of new elites and their agendas. So it is not surprising that a large proportion of the energy one identifies in post-revolutionary Soviet society was invested in message control, the building of a narrative that endowed the revolution with as much creative energy as possible, and that inserted as much space and substantive difference as possible between the Old and New Regimes.

In their study of revolutionary elites' use of images, concepts, and terminology, Figes and Kolonitski emphasize the intense exploitation of new language at this moment not only to interpret, but to create difference between the New and Old Regimes. ${ }^{99}$ But explaining why the revolutionary elite demanded the kind and intensity of practical administrative control that they sought is not easy. Russian Social Democracy was a political movement that had frequently exhibited the strong anti-state bias that would surface during War Communism. Nevertheless, Lenin's statements of purpose for post-revolutionary administrative construction in State and Revolution made clear his intention to use state organizations to achieve the revolutionary end of radical regime change. He rationalized the contradiction by arguing that one could separate "bureaucracy" from state power, thereby legitimately mobilizing state organizations and personnel for revolutionary goals. ${ }^{100}$

99 Figes and Kolonitskii, Interpreting the Russian Revolution; but also see Frederick C. Corney, "Narratives of October and the Issue of Legitimacy," in Russian Modernity, 185-203; and Peter Kenez, The Birth of the Propaganda State. Soviet Methods of Mass Mobilization, 1917-1929 (New York, 1985).

100 An essay by Eric Olin Wright considers this issue at length without, however, setting it into an institutionalist context, a puzzling fact given his acknowledged indebtedness to a pioneering the- 
In part, the problem of the Bolshevik quest for state power arose because the Revolution happened when it did. This is a point that has been made in different ways by others. As noted above, Kotkin links the meaning of the revolution to the emergence of a new social consciousness during and after World War I, a conjuncture that others have identified as the culmination of "high modernism," in the phrase of James C. Scott. ${ }^{101}$

The first half of the twentieth century was the era par excellence of state intervention in modern economic development across the entire industrialized world. Even before 1900 there was a growing perception in Russia, Europe, and North America that planning was the best way to achieve efficient, rapid, humane industrial growth and that the state was needed to manage the planning. ${ }^{102}$ Russia in the 1920 s was only one of many places where these ideas gained legitimacy among social scientists, economists, and the political left wing (owing to concern about the welfare of workers during economic downturns that planning was expected to obviate).

What was special about the Soviets' situation (as compared to European and North American countries where these agendas were also being raised) was their need to do things in a "revolutionary" way coupled with Lenin's serious intent to use any necessary amount of the state structure and personnel they inherited from the Old Regime to achieve revolutionary objectives. While he famously dangled the prospect of a diminished state whose clerking and filing activities could be discharged by a few modestly trained workers, robust state intervention was the post-revolutionary outcome that Lenin actually predicted in State and Revolution. ${ }^{103} \mathrm{He}$ squared the circle by asserting that this outcome would be accompanied by a proletarianization of state authority that would "smash" bureaucracy (but not honest and necessary state administration). This is a policy strategy that at least some institutionalists would recognize as a purposive attempt to transform institutions while relying on existing organizational structures and personnel. Lenin's purpose, that is, was to replace institutions that, in fact, endured and prospered. Nevertheless, through exploitation of new language and new communication techniques, the revolutionaries aggressively branded both intent and power-both resurrected organizations and enduring institutions - as the trademarks of their New Regime. Institutionalist theory and methods may help scholars to narrate the validity of those revolutionary claims, but that is not guaranteed.

orist of institutionalism, Reinhard Bendix. See "To Control or to Smash Bureaucracy: Weber and Lenin on Politics, the State, and Bureaucracy," Berkeley Journal of Sociology (1975):70-108.

101 Scott, Seeing Like a State, 4-6, 342-57.

102 Stanziani, L'Économie en révolution, 45-58, recognizes this changing environment at the turn of the century. But the work's focus on the agrarian economy fails to capture the full force of this thinking among social scientists and some engineers who tended to privilege the importance of manufacturing and infrastructure development.

103 Lenin, State and Revolution; see ch. 3, "What is to Replace the Shattered State Machinery?" and following sections, 35-48. 